\title{
Shifting power relations in New Zealand child welfare policy: The process and implications of the 2014 amendment to s13 of the CYP\&tF Act
}

Sarah Martin Graduate of the Masters of Public Policy, School of Government, Victoria University of Wellington.

\begin{abstract}
INTRODUCTION: The Vulnerable Children (VC) Act 2014 amended section 13 (s13) of the Children, Young Persons and their Families (CYP\&tF) Act 1989 to re-emphasise the principle that the welfare and interests of the child should be the paramount consideration in child protection proceedings. This study examines the policy process behind the amendment, and investigates its possible implications, in particular its impact on the power relationship between the state and family/whānau.
\end{abstract}

METHOD: Data was collected from semi-structured, confidential interviews with 10 key informants. Key themes were identified using thematic analysis. This was supplemented by document analysis of published and unpublished government papers, consultation papers and local and international research.

FINDINGS: The policy process that preceded the decision to amend 13 of the CYP\&tF Act was controlled by a small policy elite that failed to consult broadly on either the need for the amendment, or its impact on vulnerable children and families. Government gave little consideration to the implications of the policy change, and the policy process used to develop the amendment lacked the characteristics of rational, comprehensive, policy development. No evaluation or monitoring of the policy change has been put in place, despite the known risk that it may result in an increase in unnecessary removals of children from their families/whānau.

CONCLUSION: The s13 amendment, while appearing minor, has significant implications for vulnerable children and families and is part of a fundamental re-balancing of power relations in New Zealand's child welfare policy.

KEYWORDS: Vulnerable Children's Act 2014; Children Young Persons and their Families Act; paramountcy of the child; rational-comprehensive policy development; power

AOTEAROA

NEW ZEALAND SOCIAL WORK 28(2), 40-50.

CORRESPONDENCE TO: Sarah Martin sbmartini@gmail.com

\section{Introduction}

In 2014 the New Zealand Government made a number of changes to child welfare policy through its Children's Action Plan - a suite of policy, legislative and institutional reforms introduced following a White Paper on Vulnerable Children. The reforms were enacted by the VC Act (2014) and were touted as "the most comprehensive changes to policy and services for children vulnerable to maltreatment since the passage of the Children, Young Persons, and their Families [CYP\&tF] Act 1989" (Ministry of Social Development (MSD), 2012a, p.4). 
The omnibus VC Act (2014) contains a wide range of legislative measures that aim to ensure that "New Zealand's most at risk children get priority in accessing services and support" (Bennett, 2014a, p.1). The VC Act legislates for joint agency accountability for the wellbeing of vulnerable children and establishes a "solid platform of accountability and monitoring never before seen in child protection" (ibid).

This article is based on research undertaken as part of a Masters in Public Policy and examines one small, but significant, change introduced by the VC Act: the insertion into section 13 of the CYP\&tF Act the first and overriding principle that the welfare and interests of children must be the paramount consideration in child protection proceedings. In effect, this elevates the principle of the paramountcy of the child above the family/whānau-centric principles in the remainder of s13 and that are also found in 55 of the Act. It also strengthens the pre-existing paramountcy of the child principle found in $\mathrm{s} 6$ of the Act.

Research material was gathered through primary and secondary research methods. Primary research consisted of: confidential, semi-structured, qualitative interviews with ten key informants; the collection and analysis of published and non-published government papers; and the analysis of public consultation documents. The ten key informants were selected on the basis of their knowledge of, and expertise in, child protection policy, practice and legislation in New Zealand. They included community social workers, academics, legal and medical professionals, and representatives from the broader public and social services sector. Three of these were able to provide analysis of the legislative change from a Māori perspective. Interviews took place either in person or over the telephone and were conducted between December 2014 and April 2015. The interviews were conducted on the basis of a guarantee of confidentiality and anonymity: for reporting purposes participants were assigned a number from
1 to 10 , and a randomly assigned gender. Secondary research involved the collation and analysis of existing research into child welfare policies, practice and legislation in New Zealand.

Government papers reveal that the s13 amendment was the product of a policy process that lacked the cornerstone elements of a rational-comprehensive approach to policy making. The decision to amend the legislation was based on the evidence of one report that had investigated service failure in one case of child maltreatment (Smith, 2011). The evidence and analysis of this report was uncontested by officials, and no other evidence was considered. Furthermore, the Government knew that the s13 amendment could potentially result in an increase in the number of children removed from their families, yet no steps have been put in place to monitor and evaluate the impact of the policy change. In addition, despite the fact that the policy change had the potential to undermine the whānau-centric principles of the Act, no specific consultation with Māori was undertaken.

Thus the s13 amendment appears to have been driven by a populist desire on the part of the Government to be seen to be "doing something", by limiting the parenting rights of "bad parents", rather than by wellresearched evidence on the effectiveness of the legislation. The direction of the amendment is consistent with dominant ideological paradigms in New Zealand and elsewhere, which take an individuated and punitive approach to family dysfunction. Parents are to be blamed and punished for failing to care for their children, rather than supported and rehabilitated. This neoconservative framing of "bad" parents sits alongside a neo-liberal economic discourse that justifies the removal of resources and rights from the "undeserving" parents.

The s13 amendment, along with other provisions of the VC Act, represents a fundamental departure from the original spirit and intent of the CYP\&tF Act. 
The VC Act amendments re-balance the relationship between state and families, as power is shifted firmly back towards the state and professionals and away from parents and families. As such the dominant role of the state has become a paternalistic, authoritarian "rescuer" of children, and the rights of parents have been diminished. In essence, this moves New Zealand child welfare policy back towards its pre-1989 character.

\section{The paramountcy principle}

One of the key philosophical debates that surrounded the creation of the CYP\&tF Act in 1989 related to the paramountcy principle. It had become emblematic of a welfare approach that conflicted strongly with the Māori belief that children should not be isolated from their whānau, and that privileged the view of professionals over families: "the current [paramountcy] principle is seen in practice as negating the right of the group to care for its own or to be heard in the proceedings" (Ministerial Advisory Committee, 1988, p.29). To address this, the legislative review working party concluded that "there should be a presumption in favour of the family and whānau" (Dalley, 1998, p.355), and the principle that the welfare of the child should be the paramount consideration was excluded from the 1989 legislation.

This was met with criticism by opposition politicians, some medical and legal professionals, and child advocacy groups who were concerned that the welfare of some children could be threatened by the empowerment of their families (Barrington 2004, Connolly 1994). The 1992 Mason Review, "concerned by what it interpreted as the minimization of children's rights in favour of maintaining family integrity" (Dalley, 1998, p.360), recommended the reinstatement of the paramountcy principle into the legislation. Accordingly, the CYP\&tF Amendment Act (1994) inserted the s6 principle that "In all matters relating to the administration or application of this Act ... the welfare and interests of the child or young person shall be the first and paramount consideration (CYP\&tF Act 1989).

Between 1994 and 2011, the principle of the paramountcy of the child seemed to disappear from government policy agendas. However, in 2011, the question of whether the CYP\&tF Act gave sufficient weight to the principle became central to a debate about the ability of child welfare services to protect vulnerable children.

In January 2011 the Minister of Social Development, Paula Bennett, appointed former ombudsman, Mel Smith, to lead an inquiry into the case of a nine-year-old girl who was seriously abused while her and her family were receiving services from a number of government agencies, including the Department of Child, Youth and Family Services (CYF). The key finding of the subsequent report (the Smith report) was that the legislation did not adequately express the paramountcy of the interests of the child. Smith (2011) recommended that other considerations should be subordinate to the paramountcy principle as found in $\mathrm{s} 6$ of the CYP\&tF Act. Ultimately this led to the 2014 amendment to s13 of the CYP\&tF Act.

\section{The policy process and the s13 amendment}

The rational-comprehensive model of policy development portrays a process whereby values and objectives are considered alongside a scientific and rational assessment of evidence, solutions and consequences (Howlett and Ramesh, 2003, Hill 2013, Shaw and Eichbaum, 2011). While this approach underestimates the role of politics in policy development, its value lies in its insistence that policy decisions should be informed, if not constrained, by evidence, which includes the consideration of consequences. Key tools of a rational comprehensive approach to policy development include systems analysis, causal mapping and intervention logic. System analysis should also include 
widespread stakeholder consultation: "policy must consult outside the game not only to retain legitimacy but also to respond innovatively and effectively to policy challenges" (Scott and Baehler, 2010 p.60).

The s13 amendment to the CYP\&tF Act was made as part of a suite of legislative amendments introduced by the VC Act. The publicly available Regulatory Impact Statement (RIS) (MSD, 2013) that accompanied the April 2013 Cabinet Paper on the Vulnerable Children Bill notes that:

Concerns have been raised by some, for example in a report by Mel Smith, that the principles of the CYP\&tF Act are ambiguous and allow for an interpretation which places undue weight on the interests of the family and the need to keep the child within the family which could come at the expense of the safety and wellbeing of the child. (MSD 2013, p.5)

On the basis of this statement, in August 2014 I made an Official Information Act (OIA) request to MSD for details of these "concerns" and for documents detailing the policy background to the s13 amendment. The bulk of my OIA request was declined. Nonetheless, MSD agreed to release four documents to me (three of which were heavily redacted). In an accompanying letter to me on behalf of the Ministry, the Acting General Manager Child, Family and Community Policy, Peter Galvin, traced the history of the s13 amendment.

According to Galvin, the genesis of the s13 amendment lay in the policy work undertaken in 2007 to update the CYP\&tF Act, where public submissions revealed "concerns about the CYP\&tF Act" (Galvin, 2014, p.1). The resulting CYP\&tF Amendment Bill (No 6) 2007 contained significant reforms to the Act - but no proposed amendment to the paramountcy principle - and was discharged by the incoming Government in 2008.
Galvin reports that the next step towards change came with the release of the Smith report in March 2011: "the report discussed whether sections 5,6 and 13 of the CYP\&tF

Act result in the loss of focus on the interests of the child" (ibid). Later that year the Green Paper for Vulnerable Children (MSD, 2011) was released for public consultation. Although Galvin cites submissions to the Green Paper as another important milestone in the move to legislative change, I found no evidence of significant advocacy for change from submitters. A search of the document summarizing submissions found only two references to the CYP\&tF Act. In one instance it recorded that "a small minority drew attention to the legislation" (MSD, 2012b, p.157).

The submissions of the major children's interest organisations to the Green Paper do not demonstrate advocacy for a change to the legislation. The submissions of the Children's Commissioner and the Social Workers Registration Board expressed support for the CYP\&tF Act, both finding that it "provides a sound legislative platform for balancing the roles of family and whānau and children in as far as the care and protection system is concerned" (Wills, 2011, p.1). There were a large number of submissions to the Green Paper from Māori organisations. My survey of these found no reference to the need to rebalance the principles of the CYP\&tF Act.

Despite the endorsement of the CYP\&tF Act from major child advocacy organisations and representatives, by the time the White Paper on Vulnerable Children was released, reform of the principles of the CYP\&tF Act had become a key priority for government action. The White Paper was released in October 2012 and foreshadowed the amendment to the s13 principles. It presented the two main reasons for legislative reform as being: first, to achieve legislative clarity; and second to send a signal of the Government's desire "for all those working with children to shift towards child-centred practice, and ensure that children's wellbeing is at the heart of all decision-making" (MSD, 2012a, p.160). 


\section{Behind the scenes}

A January 2012 memo from MSD to unknown (redacted) recipients, released to me under the OIA, preceded the release of the White Paper and provides the most fulsome expression of the Government's policy deliberations on reform of the principles of the CYP\&tF Act (MSD, 2012c).

In the background section of the report, officials cite the findings of the Smith report on the potential ambiguity of the CYP\&tF Act's objects and principles. The paper notes Smith's finding that there was a potential conflict in the principles of the Act "leading to a loss of focus on the interests of the child as paramount, and the appearance that the wishes of a parent or parents, and/or whānau prevailed over the immediate and long term best interests of the child" (MSD, 2012a, p3). Officials cite Smith's key finding that:

As a general rule, it was postulated to me that the provisions in ss 5 and 13 have become dominant in the minds and in the practice of social workers, and others involved in the process, to the possible detriment of the safety, welfare and interests of the child. (p.82).

No other research or evidence regarding the legislative principles is cited in the paper. Moreover, officials admit on three occasions that there is no strong evidential link between the legislative principles (as they existed prior to the 2014 amendment) and child protection practice that had failed to protect the best interests of children. On page three officials advise that "if evidence of a problem with decision-making is found, it cannot be assumed that the principles of the CYP\&tF Act are contributing to the issue. The issue may be one of practice that could be effectively addressed within the existing principles of the Act (p.3). Later they note that it is "unclear whether the principles have caused practice issues" (p.5). Officials also report that "the courts have not indicated any particular difficulty with the interpretation of the principles" (p.4).
Nonetheless, the paper concludes that the proposed "changes to the way the principles of the Act are expressed are sufficient to address a concern regarding an insufficiently child-centred and safety focused approach by practitioners" (p. 6). The case for change as outlined in the above memo was carried through into Cabinet papers and resulted in the legislative amendment to $\mathrm{s} 13$ of the CYP\&tF Act.

Papers show that officials advised Ministers of two significant risks associated with the proposal to re-balance the principles of the Act in favour of the paramountcy of the child. It could lead to "potentially overly risk averse approaches by social workers, for example, removing children where there is a risk of harm despite other considerations weighing in favour of keeping the child in the family" (MSD 2012c, p.5, MSD 2013 , p.14). Officials also note that the "appropriateness of this in the context of Māori concepts of child and family wellbeing would need to be considered" (MSD 2013, p.14).

Officials were thus aware that the amendment could lead to an increase in the unnecessary removal of children from their families and that it could undermine the whānau-centric principles which are a cornerstone of the Act. As I considered these to be significant risks, I sought from MSD information on: what consideration had been given to the impact on social work practice of the amendment and whether any evaluation measures were in place; and details of any specific consultation undertaken by MSD with Māori and Pacific people on the 2014 amendments to the principles of the CYP\&tF Act (1989).

The reply I received from Maree Roberts, General Manager, Child, Family and Community Policy at MSD stated that

whilst no specific consultation with Māori and Pasifika was undertaken by the Ministry, the Bill was subject to the standard legislative (and consultation) 
process and was referred to the Social Services Select Committee in September 2013 where public submissions were invited. (Roberts, 2015, p.1)

Furthermore, "as the amendments to s.13 did not fundamentally alter the care and protection principles...no consideration of its impact, or measurement of its future impact was necessary" (ibid, p.2).

\section{A rational-comprehensive approach?}

The Government's decision to amend s13 of the CYP\&tF Act appears to have been informed exclusively by the evidence provided in the 2011 Smith report and his argument that practice failures had arisen from a lack of legislative clarity. There is no evidence in the papers I have seen to indicate that the Government considered a range of alternative solutions and their consequences before deciding to change the legislation. Nor is there any evidence of engagement with a broad range of stakeholders.

The lack of comprehensive systems, causal or impact analysis, the failure to consider a full range of policy options and the absence of widespread consultation, indicates that the policy process that led to the s13 amendment lacked the characteristics of a rationalcomprehensive approach to policy making. In an area of social policy that is so beset by emotions, government officials play a critical role in ensuring that decision-making is also informed by a robust, rational and comprehensive policy process, with strong links made between evidence, policies, and outcomes. Facts should feature as much as values in determining policy change. Furthermore, the policy process should be inclusive, and the policy change supported by a range of stakeholders, including those outside the power elite.

\section{The Government's political intentions}

The absence of such an approach suggests that the change to s13 was driven more by political motivations rather than by strong evidence. Within a democratic system of government, Ministers must be allowed to pursue political agendas and a rational-comprehensive approach to policy development should not prohibit this. Acknowledging that public policymaking is a political pursuit is important in understanding the underlying determinants of policy changes.

The agenda-setting and alternative specification phases of the policy cycle are pivotal in an analysis of power because they frame both the policy problems and the solutions that the Government will consider, and therefore conscribe government action. The subjective and normative aspects of these activities make them worthy of attention as the problems and policies that are deemed to merit consideration by government will reflect the values of the relevant dominant policy actors (Shaw and Eichbaum, 2011, Howlett and Ramesh, 2003).

The Smith report played a significant role in the agenda-setting activity that preceded the s13 amendment, in particular identifying the policy problem and a proposed policy solution. In his report Smith argued strongly that the legislation was problematic. The "conflict" in the Act between the principle of the paramountcy of the child and those principles that assert the primary caring role of the family had led to practice that was insufficiently child-centred and had thus jeopardized the safety of children (Smith 2011).

This could be fixed, he argued, by pushing the child welfare pendulum back towards a focus on the protection of the child. Thus, he recommended that all principles in the Act should be subordinate to the paramountcy principle. Of the ten people I interviewed, only two agreed with Smith's analysis. Eight thought that poor practice arose from inadequate training and resourcing rather than legislative ambiguity, although one of these people thought that strengthening the paramountcy principle could benefit practice. 
Although Smith argues strongly that the problem lay with the legislation, he acknowledges the difficulty of developing policy on the paramountcy principle. He describes his surprise at the lack of research into the administration and application of the various principles of the Act, and finds that "the complexity and indeed the politics of the issues, the absence of well researched and analysed experience render it impossible to develop sound, reasoned and developmental arguments on which to base law and policy" (op cit., p.83).

Despite the lack of causal evidence linking the problem of insufficiently child-centred practice with the legislation - something noted by both Smith and officials - Smith's problem recognition was consistent with dominant risk-averse approaches to child welfare policy and was thus accepted by the Government. His analysis resonated with the political motivations and ideological framework of a government that wanted to show it was getting tough on problem parents. As Kingdon (1984) argues, a receptive political climate is critical to a policy issue making it onto the agenda:

Potential agenda items that are congruent with the current national mood, that enjoy interest group support or lack organized opposition, and that fit the orientations of the prevailing legislative coalitions or current administration are more likely to rise to agenda prominence than items that do not meet such conditions. (p.21)

In policy changes introduced by the VC Act 2014 we see the Government's interpretation of Kingdon's "national mood" (ibid) as being a desire for a stricter, more interventionist role for the state in protecting children. The intention to translate public sentiment into "bold legislation to protect children" was expressed very clearly by the Minister for Social Development when she introduced the legislation: "we've all had enough, it just had to stop... the community signed up to this, New Zealanders asked us to take real action to make a difference. We're doing exactly that" (Bennett, 2013, p.1).

Hyslop (2009) describes the national mood in New Zealand in relation to child welfare as one of high and escalating anxiety, which originates from our growing awareness of the fallibility of modern child welfare systems. Paradoxically, the growing media interest in, and public awareness, of child abuse and maltreatment, has fuelled this anxiety with an expectation that "social workers could and should, protect all children from harm" (Connolly \& Doolan, 2007, p.1). This has resulted in "increasingly shrill demands for the design and application of stringent measures to predict and reduce risk" (Hyslop, 2009, p.64).

Of course, a "national mood" doesn't exist in a vacuum; rather is it heavily influenced by the ideologies promulgated by the political elite and the policy agenda will be tightly circumscribed by consistency with this ideology. The changes introduced by the VC Act reflect the influence of two dominant ideologies: an economic neoliberalism that has prevailed since the mid-1980s and an emerging neo-conservatism of social values. Lonne, Parton, Thomson \& Harris (2009) describe the interaction of these two dominant ideologies as creating "a blaming, punitive and socially divisive ideology ... leaving little room for social care as opposed to social control" (p.72).

Within this framework the resources of the state are strictly limited to those who "deserve" them, whilst the "undeserving" are punished for their failures as individuals through the loss of certain rights and state support. Failure to meet normative parenting standards is analysed on an individuated basis, rather than through structural causality. Thus, Bennett stresses that vulnerability in children is largely the fault of their parents: "while many risk factors, or confluence of factors, play an important role in vulnerability and resilience, the most important factors are parental behavior, action and failure to act" (Bennett, 2012, p.3). 
A critical component of this dominant ideology is the construction of a divisive "them and us" discourse, which presents an ideal-type of normal, good parenting, against which "bad" and "unworthy" parents are compared. As part of this discourse parents (especially mothers), are often portrayed as selfish, placing their own needs ahead of those of their children (Featherstone, White \& Morris, 2014). The majority of citizens generally accept the increased intervention and surveillance powers of the state because they judge (mostly correctly) that they won't be affected by these activities. Keddell (2014) comments that the underlying message of the VC Act is that parents, by not being "prudential citizens, deserve to be punished and [have their] children removed. The loss of parental rights is legitimate" (p.22).

\section{Participants}

Public policy is a social construction, reflecting dominant and normative social values. Therefore, to gain insight into the motivations behind a policy decision, it is vital to understand who has participated in a policy process and whose opinions have been privileged. At the same time, knowing whose views have been excluded "reveals a good deal about the process of policy formulation and the genesis of policy decisions" (Shaw and Eichbaum, 2011, p.26).

The critical time for engagement of outside groups in the policy development process is during the agenda setting and policy formulation phases, which are generally dominated by the executive and civil service bureaucrats respectively (Kingdon, 1984). Notwithstanding the engagement of a broad range of interest groups in the Green Paper and at select committee stage - which could support a pluralist interpretation of the policy process - the policy processes surrounding the s13 amendment appear to have been restricted to an elite group of policy officials, Ministers, and possibly a small number of like-minded individuals. The government papers that I have seen do not discuss the views of key stakeholders and no mention is made of any consultation having been undertaken. The centrality of Smith - who was appointed to the review by the Minister - in defining the policy problem, accords with Kingdon's (1984) finding that it is "elected officials and their appointees" who have the most influence in shaping the agenda, not "career bureaucrats or nongovernmental actors" (p.20).

Interestingly, the two key informants I interviewed who had been involved to some extent with the Smith report were the only informants who supported the official narrative that ambiguous legislation was a causal factor. The other informants considered poor practice to be linked more to structural factors such as resourcing and training rather than legislation. Addressing these factors would have required policy solutions that were are not consistent with the current Government's fiscal and ideological paradigms. Similarly, one of the people I interviewed thought that no specific consultation had been undertaken with Māori - despite the historical interest from Māori in the paramountcy principle because "they would get what they got at Puao-te-ata-tu: Māori for Māori" (Participant 10). This points to the operation of a policy community of like-minded individuals, officials and decision-makers and the existence of insider and outsider groups. Outsider groups are excluded from influential policy communities "through choice, ideological orientation... or because they advocate contentious causes (Shaw and Eichbaum, 2011, p. 197).

Officials' careful imaging of the policy problem as one of legislative drafting suggests the operation of a policy monopoly (Baumgartner and Jones, 1991). The risks identified by MSD go to the heart of the spirit and intention of the CYP\&tF - that of family maintenance and family empowerment - yet the Government's portrayal of the problem as one of legislative confusion downplayed the political implications associated with strengthening the paramountcy principle. This careful imaging of the problem 
allowed the Government to curtail outsider involvement in the policy discussion, despite the fact that the issue of paramountcy was a key site of ideological debate during the creation of the CYP\&tF Act.

The minimization of the effect of the legislative amendment on the principles of the CYP\&tF Act accords with Kline's (1992) argument that the impartial and apolitical pretensions of child welfare law belie its deeply ideological foundations. The assumed national consensus in support of child welfare policies portrays dominant ideologies as "natural" and serves to "obscure material relations of conflict and oppression" (p.416).

\section{Shifting power relations}

One of the main findings of this research has been that the s13 amendment is part of a suite of changes to the CYP\&tF Act that signals a departure from the original intentions of the legislation, as power is shifted away from families and back into the hands of professionals. This is achieved with the insertion into the CYP\&tF Act of the strengthened paramountcy principle (s.13), and new guardian and subsequent children provisions in the Act. Together, the amendments see the primary role of the state move back towards that of paternalistic rescuer or protector of children, while the rights of parents are diminished.

The dominance of the bureaucratic and power elite in the decision to amend s13 means that the problems, and the solutions, were very much constrained by these policy actors' worldviews. As such, the resultant policy privileges the normative social, cultural and political values of the elite, rather than the people who will be most affected by the policy.

The principles of paramountcy and the best interests of the child are by no means politically neutral concepts: interpretations of what is in the best interests of the child will tend to reflect the values of the power elite and will necessarily marginalize those outside the power elite - working class families and families from ethnic minorities. Cooke (2013) argues that the 56 paramountcy provision of the CYP\&tF Act, prior to the s13 amendment, exemplified state paternalism and the "notion that professionals, social workers and judges being middle-class decision-makers know what is best according to their value systems" (p.178). This analysis is echoed by one of my interviewees who said that, "paramountcy always gave the Crown the right to intervene in a manner justified for them".

By strengthening the prominence of the paramountcy provision the s13 amendment embeds the notion of professional preeminence over parents and undermines the power relationship envisaged by the CYP\&tF Act. The amendment not only diminishes the role and power of the family but also potentially signals a return to the dominance of Eurocentric values in child welfare policy that the CYP\&tF Act had sought to overturn.

The shift in power relations reflects ascendant social values on the role of the state and the responsibilities and rights of parents. The policy enhances children's rights to state protection as individuals but also the interventionist role of the government. Parental rights are consequently reduced, a fact made politically palatable to the public as it is delivered alongside a rhetoric that demonises an underclass of unworthy parents.

\section{Conclusion}

Nutley et al (2009) and Gregory (2004) argue that policy processes would be greatly improved if they allowed for the genuine participation and engagement of a greater range of participants, including those upon whom polices impact. While the enablement of a multiplicity of voices, many of whom are likely to challenge existing paradigms, would be difficult, "such open, pluralistic, interactive and informed policy communities have exciting possibilities and democratising potential" (Nutley, Walter \& Davies, 2013, p. 22). 
In many ways, these descriptions of the ideal policy development process - informed by a range of voices, including those who challenge the status quo - describe the process that produced the original CYP\&tF Act in 1989. The involvement of participants from outside the governing elite in the policy development process resulted in a significant transfer of power from the state to families and whānau. The most recent reform of child protection policy has taken the opposite approach, privileging the views of a policy elite and signalling a rebalancing of power back to the state.

Concerns about the increased emphasis on the paramountcy principle arise not because people disagree with notion that the welfare of the child should be the central concern of child welfare policy. Rather, they reflect the fact that the principle invests greater power in professionals and that the determination of the best interests of that child will naturally be subjective, and heavily influenced by dominant and normative definitions of family life. In the ideological and practice environment described above, the definition of best interests of the child is likely to be considerably narrowed. Moreover, those most likely to fail statedefined standards of adequate parenting are single-parent (mostly female) families from ethnic minorities and the working class. Indeed official papers show that the policy change could lead to an increase in the unnecessary removal of children from their homes, yet nothing has been put in place to monitor and evaluate this potential impact.

The policy process used to develop the s13 amendment stands in stark contrast to that used to develop the CYP\&tF Act in 1989. That latter legislation was introduced after a long, inclusive and comprehensive process. The Government deliberately and pro-actively sought to understand the views and values of Māori, and these became the blueprint for the legislation. It is concerning that in the decision to amend s13, which fundamentally erodes some of those core values, no effort was made by the Government to consult specifically with Māori. The VC Act is a piece of mainstream legislation that disproportionately affects Māori children and families; as such greater participation by Māori in the decision making process should have occurred. Further analysis and investigation of this issue is necessary.

\section{References}

Barrington, J. (2004). A Voice for Children: The Office of the Commissioner for Children in New Zealand 1984-2003. Wellington: Dunmore Press. Retrieved from http://www.occ.org.nz/assets/Uploads/OCCAVoiceforChildren-010104.pdf

Baumgartner, F.R., \& Jones, B.D. (1991). Agenda dynamics and policy subsystems. The Journal of Politics 53(4), 1044-1074.

Bennett, P. (2012). White Paper on Vulnerable Children. Paper to Cabinet Social Policy Committee, September 2012. Wellington, Ministry of Social Development. Retrieved from http://www.msd.govt.nz/documents/ about-msd-and-our-work/work-programmes/policydevelopment/white-paper-vulnerable-children/whitepaper-cabinet-paper.pdf

Bennett, P. (2013). Bold legislation will protect children. Retrieved from http://beehive.govt.nz/release/boldlegislation-will-protect-children

Bennett, P. (2014a). Vulnerable Children Bill Passed into Law. Retrieved from https://www.beehive.govt.nz/ release/vulnerable-children-bill-passed-law

Bennett, P. (2014b). Vulnerable Children Bill Passed Into Law. Retrieved from https://www.national.org.nz/news/ news/media-releases/detail/2014/06/19/vulnerablechildren-bill-passed-into-law

Connolly, M. (1994). An act of empowerment: The Children, Young People and their Families Act, British Journal of Social Work, 24, 87-100.

Cooke, A. (2013). State responsibility for children in care (Doctoral thesis, University of Otago, Dunedin, New Zealand). Retrieved from https://ourarchive.otago. ac.nz/bitstream/handle/10523/4796/ CookeAllanJ2014PhD.pdf?sequence $=1$

Dalley, B. (1998). Family matters: Child welfare in twentiethcentury New Zealand. Auckland: Auckland University Press.

Featherstone, B., White, S., \& Morris, K. (2014). Reimagining child protection: Towards humane social work with families. Bristol: Policy Press.

Galvin, P. (2014). Letter to the author in response to a request under the Official Information Act.

Gregory, R. (2004). Political life and intervention logic: Relearning old lessons? International Public Management Review, 5(2), 1-12.

Hill, M. (2013). The public policy process $\left(6^{\text {th }}\right.$ ed). Essex: Pearson.

Howlett, M., \& Ramesh, M. (2003). Studying public policy: policy cycles and policy subsystems, $\left(2^{\text {nd }}\right.$ ed). Ontario: Oxford University Press. 
Hyslop, I. (2009). Child protection policy and practice: A relationship lost in translation. Social Policy Journal of New Zealand, 34, 62-72.

Keddell, E. (2014). The White Paper on Vulnerable Children and welfare reform in Aotearoa New Zealand: Two sides of the same coin? Paper presented at the Social Work Social Development conference, Melbourne, Australia.

Key, J. (2011). Statement to Parliament 2011. Retrieved from http://www.beehive.govt.nz/feature/statementparliament-2011.

Kline, M. (1992). Child welfare law, "best interests of the child" ideology, and first nations. Osgoode Hall Law Journal $30(2), 375-425$.

Kingdon, J. W. (1984). Agendas, alternatives and public policies. Boston: Little Brown.

Lonne, B., Parton, N., Thomson, J., \& Harris, M. (2009). Reforming child protection. New York: Routledge.

Ministerial Advisory Committee on a Māori Perspective for the Department of Social Welfare (1988). Puao-Te- Ata-Tu. Retrieved from https://www.msd.govt.nz/documents/ about-msd-and-our-work/publications-resources/ archive/1988-puaoteatatu.pdf

Ministry of Social Development. (2011). Every child thrives, belongs, achieves: green paper for vulnerable children. Retrieved from http://www.msd.govt.nz/documents/ about-msd-and-our-work/work-programmes/policydevelopment/green-paper-vulnerable-children/greenpaper-for-vulnerable-children.pdf.

Ministry of Social Development. (2012a). The White Paper for Vulnerable Children, Volume II. Retrieved from http://www.msd.govt.nz/documents/about-msd-and-ourwork/work-programmes/policy-development/white-papervulnerable-children/whitepaper-volume-ii-web.pdf

Ministry of Social Development. (2012b). The green paper for vulnerable children: Complete summary of submissions. Retrieved from https://www.msd.govt.nz/ documents/ about-msd-and-our-work/work-programmes/ policydevelopment/green-paper-vulnerable-children/thegreen-paper-for-vulnerable-children-submissions.pdf

Ministry of Social Development. (2012c). Amending the objects and principles of the Children, Young Persons and Their Families Act 1989. Memo to unidentified recipients, released to the author under the Official Information Act.

MSD. (2013). Regulatory Impact Statement. Vulnerable Children's Bill: Specific care and protection legislation changes. Retrieved from https://www.msd.govt.nz/ documents/about-msd-and-our-work/publicationsresources/regulatory-impact-statements/vulnerablechildren-s-bill-specific-care-and-protection-legislationchanges.pdf

Nutley, S., Walter, I. \& Davies, H. (2009). Past, present and possible futures for evidence-based policy. In G. Argyrous (Ed.), Evidence for policy and decisionmaking: A practical guide (pp. 1-23). Sydney: UNSW.

Roberts, M. (2015). Letter to the author in response to a request under the Official Information Act.

Scott, S., \& Baehler, B. (2010). Adding value to policy analysis and advice. Sydney: UNSW.

Shaw, R., \& Eichbaum, C. (2011). Public policy in New Zealand: Institutions, processes and outcomes, ( $\left.3^{\text {rd }} \mathrm{ed}\right)$. Auckland: Pearson.
Smith, M. (2011). Report to Hon Paula Bennett, Minister for Social Development and Employment following an inquiry into the serious abuse of a nine year old girl and other matters relating to the welfare, safety and protection of children in New Zealand. Retrieved from http://www. beehive.govt.nz/sites/all/files/Smith_report.pdf

Wills, R. (2011). The green paper on vulnerable children: Position of the Children's Commissioner. Retrieved from http://www.occ.org.nz/assets/Uploads/submissions/ The- Green-Paper-on-Vulnerable-Children-Position-ofthe- Childrens-Commissioner.pdf 